\title{
FLUID INCLUSIONS AND TIN DEPOSITION AT ZAAIPLAATS, THE CENTRAL TRANSVAAL, SOUTH AFRICA
}

\author{
JUSSI TUOMAS OLLILA
}

\begin{abstract}
OLLILA, JUSSI TUOMAS, 1984. Fluid inclusions and tin deposition at Zaaiplaats, the Central Transvaal, South Africa. Bull Geol. Soc. Finland 56, Part $1-2,59-73$.

Fluid inclusion heating and freezing methods were used to evaluate the depositional temperatures and composition of the ore-forming fluid of the endogranitic tin deposits of the Bushveld Complex at the Zaaiplaats mine. Daughter minerals in opened inclusions were studied with a scanning electron microscope attached with an energy dispersive X-ray analyser.

The hydrothermal tin mineralization in the miarolitic cavities of the greisenized Lease granite was due to a low to moderate saline, $\mathrm{CO}_{2}$-rich fluid system. The primary inclusions in quartz, which crystallized contemporaneously with cassiterite and is associated with alkali feldspar, plagioclase, scheelite, fluorite and later-stage sulphides, have homogenization temperatures between $371^{\circ} \mathrm{C}$ and $438^{\circ} \mathrm{C}$, and salinities from 7.4 to 12.3 equiv. wt. per cent $\mathrm{NaCl}$. The primary and secondary inclusions in quartz of the unaltered Bobbejaankop and Lease granites have high, albeit variable, salinities and an extremely wide range of homogenization temperatures.
\end{abstract}

The data indicate that (i) tin mineralization within the Bobbejaankop and Lease granites depends mainly on the development of an alkali chloride-rich fluid phase, and that (ii) as a consequence of second boiling, tin was enriched and transported in a low-salinity, $\mathrm{CO}_{2}$-rich fluid phase that was obviously spatially immiscible with the coexisting hydrosaline fluid. This immiscibility segregated the tin into pipes in the Bobbejaankop granite and into greisenized, lenticular orebodies in the Lease granite.

Crystallization of cassiterite with hydrolysis vapour reaction $\mathrm{SnCl}_{4}+2 \mathrm{H}_{2} \mathrm{O}$ $\rightarrow \mathrm{SnO}_{2}+4 \mathrm{HCl}$ is possible down to $400^{\circ} \mathrm{C}$. The addition of $\mathrm{CO}_{2}$ to the water vapour reduces the growth rate of $\mathrm{SnO}_{2}$.

Key words: Bushveld granites, fluid inclusions, endogranitic tin deposition, second boiling, immiscibility, fractional crystallization, crystal growth.

Jussi Tuomas Ollila: Geological Survey of Finland, P.O. Box 77, 96101 Rovaniemi 10, Finland.

\section{Introduction}

The stratiform Main granite, belonging to the acid phase of the Bushveld Complex in the Zaaiplaats tin mining area, the Central Transvaal, forms a sheet-like intrusion beneath the Rooiberg felsites and stratigraphically overlies the metasediments of the Transvaal supergroup and the layered mafic sequence of the Bushveld Complex. Stanniferous, red, miarolitic Bobbejaankop granite has intruded into the upper parts of the Main granite as dome-like plutons (Fig. 1). The Transvaal Supergroup strata are older than $2095 \pm 24$ m.y., since they are in- 


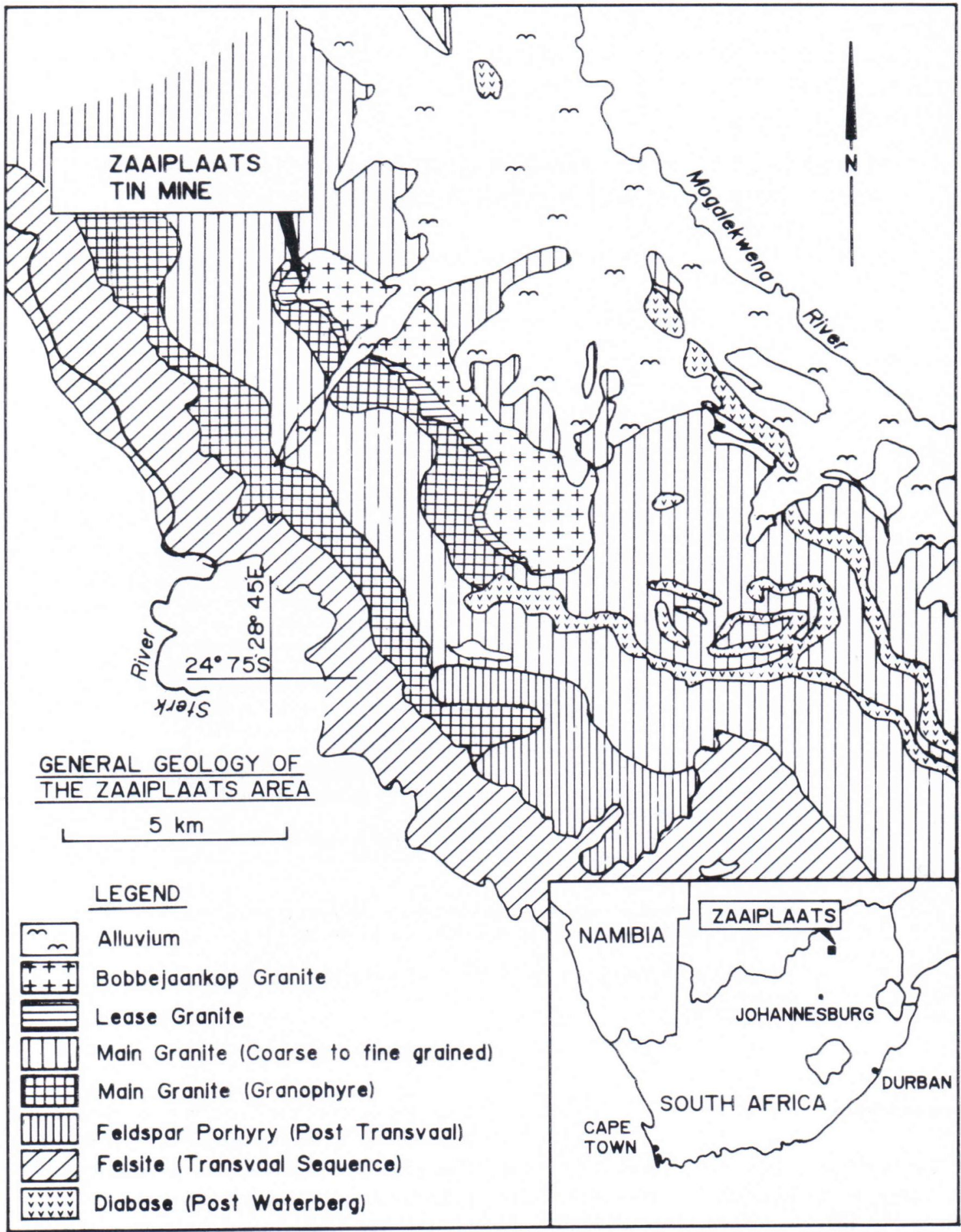

Fig. 1. Generalized geological map of the Zaaiplaats area, simplified after Lenthall and Hunter (1977). 
truded by the layered mafic rocks of the Bushveld Complex of that age. Granitic rocks of the Bushveld Complex have been dated at $1954 \pm$ 30 m.y., a figure that has been recalculated at $1870 \pm 190$ m.y. (Davies et al. 1970). All the tin deposits, viz: (i) low-grade disseminated zones; (ii) lenticular orebodies in greisenized Lease granite, which forms a metasomatized hood facies above the Bobbejaankop granite; and (iii) pipes, are confined to the roof zone of the Bobbejaankop granite. The main tin mineral, cassiterite, is usually associated with tourmaline, scheelite, fluorite, various sulphides, and gangue minerals. The mineralogy of these deposits has been described in some detail by Söhnge (1944) and Strauss (1954). This study describes fluid inclusion observations in the Bobbejaankop and Lease granites and an experiment in growing synthetic cassiterite. In addition, a possible concentration path for tin is proposed in the context of the magmatic evolution of the Zaaiplaats area.

\section{Fluid inclusion study}

Homogenization temperatures were determined using a Leitz 1350 heating stage calibrated with internal standards. The accuracy in the measured temperature range is better than $\pm 10^{\circ} \mathrm{C}$ at temperatures below $400^{\circ} \mathrm{C}$. At higher temperatures the optical difficulties to distinguish between phase boundaries limit the accuracy. Homogenization temperatures in fluid inclusions which homogenize to a liquid phase were measured two times to avoid data from leaking inclusions. Freezing and a few heating experiments were also made with the Chaixmeca heating-cooling stage in the range $-180^{\circ}$ to $+400^{\circ} \mathrm{C}$, calibrated with organic materials.

\section{Types and distribution of the inclusions}

Five types of fluid inclusions were distinguished in the examined minerals. This classification is based on the composition, degree of filling and, in Type II and III inclusions, also on the manner of homogenization. TYPE $I$ : Highly saline, with liquid, vapour, daughter $\mathrm{NaCl}$ and with or without other daughter minerals, TYPE II: Low or moderately saline with liquid and vapour phases that homogenize to a liquid phase, TYPE III: Gas-rich inclusions containing liquid and vapour phases with or without solid daughter $\mathrm{NaCl}$ that homogenize to a vapour, TYPE $I V$ : Complex three or four-phase inclusions containing aqueous liquid, liquid $\mathrm{CO}_{2}$, and gaseous $\mathrm{CO}_{2}$, and TYPE $V$ : Inclusions completely filled with a single liquid phase with or without one or more daughter minerals.

Type I inclusions of secondary origin were encountered in the specimens of magmatic quartz in both Bobbejaankop and Lease granites (Fig. 2 B). Type I inclusions presumably of primary origin are also very common in hydrothermal vuggy quartz crystals in the Bobbejaankop granite (Fig. 2 D).

Fairly large inclusions (Fig. $2 \mathrm{C}-\mathrm{H}$ ) were found in the vuggy fluorite, quartz and calcite that were sampled from one large $2 \mathrm{~m}$ long $25 \mathrm{~cm}$ high open cavity and from several other smaller vugs near the Main Adit of the Zaaiplaats mine in the Bobbejaankop granite below the disseminated cassiterite zone. In these minerals the origin of the inclusions studied could sometimes be established with fair certainty. The idiomorphic quartz crystals are sometimes 10 $\mathrm{cm}$ long, with an average length of $2-3 \mathrm{~cm}$. All these crystals have a similar inner, zoned structure. The inner core of the crystals is clear quartz followed by growth zones of milky quartz. The outer zone is clear quartz again.

Type II inclusions homogenize to a liquid phase and occur mainly in the hydrothermal vuggy minerals fluorite (Fig. $2 \mathrm{E}-\mathrm{H}$ ), quartz (Fig. 2 C) and calcite. The degree of fill and composition in some inclusions of this type is very close to the critical temperature and critical pressure of the trapped fluids. 

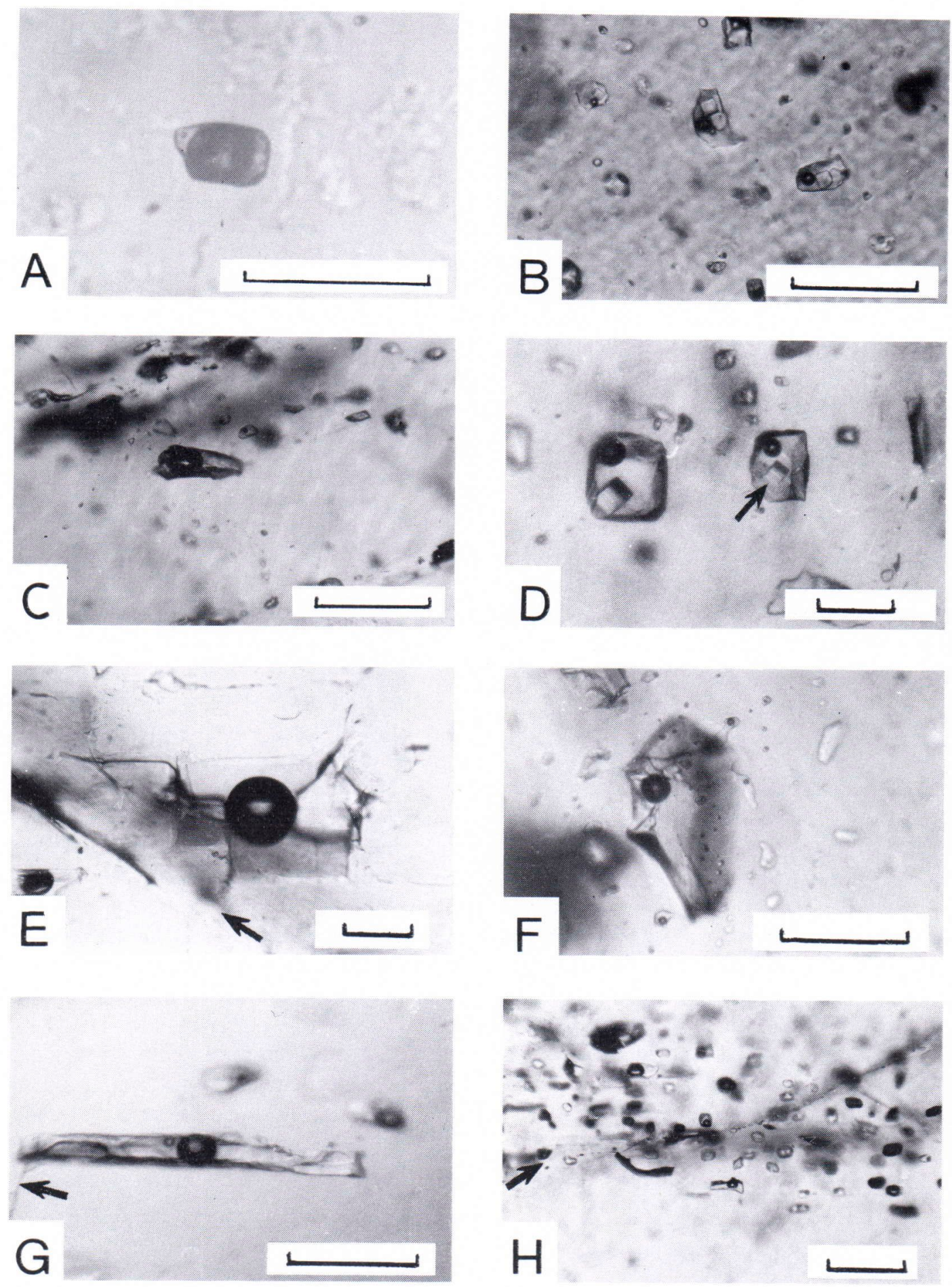

$\mathrm{H}$ 
The common fluid inclusions in original quartz of the Bobbejaankop and Lease granites are the gas-rich, Type III inclusions (Fig. 2 A). In most of the samples they occur with Type I highly saline secondary inclusions in which a cube of daughter mineral, $\mathrm{NaCl}$, is always observed in the liquid phase. Type III inclusions homogenize to a vapour phase. The Type III inclusions almost always occur singly or at most in groups of two or three, whereas the secondary Type I inclusions tend to form well defined inclusion trains in the healed fractures of the host quartz. In addition, the Type III inclusions almost invariably have well formed negative crystal forms, showing well faceted cavity walls (Fig. 3 A). Type IV fluid inclusions were found in quartz associated with cassiterite, and the appearance of the third fluid phase at some temperature slightly below $31^{\circ} \mathrm{C}$ indicated the presence of substantial amounts of $\mathrm{CO}_{2}$ in these inclusions. The idiomorphic quartz crystals in the miarolitic, mineralized vugs of the greisenized Lease granite were collected in the dormant Lease Workings. These crystals represent a contemporaneous stage of crystallization with cas- siterite, and are associated with plagioclase, alkali feldspars, scheelite, fluorite and later-stage sulphides. Type V inclusions occur as secondary inclusions in the vuggy calcite crystals of the Bobbejaankop granite.

\section{Daughter minerals}

Only a very few daughter minerals in opened fluid inclusions could be identified with certainty by the scanning electron microscope-energy dispersive X-ray (SEM-EDAX) method. Apart from halite containing some potassium in solid solution (Fig. $3 \mathrm{~A}$ ) and magnetite containing some titanium, the other phases were identified with less certainty or were not identified at all.

A daughter mineral or a trapped crystal detected in cassiterite in the mineralized Bobbejaankop granite could be xenotime, $\mathrm{Y}\left(\mathrm{PO}_{4}\right)$, or a hydroxide, oxide, carbonate or borate of yttrium, or a phosphate because the yttrium and phosphorus peaks overlap (Fig. 3 F). The daughter minerals or trapped crystals in fluorite of the mineralized Bobbejaankop granite indi-

Fig. 2. Photomicrographs of the Zaaiplaats fluid inclusions. The length of the scale bars in all photographs is $100 \mu \mathrm{m}$. A. High-gas Type III fluid inclusion in the Bobbejaakop granite consists of a bubble of compressed gas filling up to 80$90 \%$ of the inclusion cavity, and a supersaturated liquid phase with a cube of halite. Sample $06377-82$. B. The patchy distribution of the secondary, Type I fluid inclusions in a quartz grain of the Lease granite, containing both halite and sylvite as daughter minerals. Thin section $06377-19$. C. A fluid inclusion of primary origin in vuggy quartz showing a degree of filling near $50 \%$ gas and $50 \%$ aqueous brine at room temperature. It was difficult to predict the homogenization behaviour for most inclusions of this kind, viz. whether they homogenize to a vapour or to a liquid phase. Bobbejaankop granite, Sample 06377-34A. D. Two primary Type I super-saturated fluid inclusions in the inner core of a zoned, vuggy quartz crystal. The phase ratios are the same in both of the inclusions. The isotropic cubes of halite (n. -1.5443$)$ are in such close contact with the host quartz that a sensitive comparison can be made between the index of halite and the ordinary ray of quartz (n. - 1.5443); the contact (indicated by an arrow) becomes almost invisible. Bobbejaankop granite, Sample 06377-4. E. A presumably primary Type II fluid inclusion showing a well faceted, negative crystal form along a 100 plane in a host fluorite crystal. The microfracture (marked by the arrows) in the plane parallel to (111) is the cleavage direction of fluorite. Bobbejaankop granite, Sample 06377-12. F. A Type II moderately saline fluid inclusion has a rounded form and a partly euhedral crystal cavity indicating development of facets parallel to both (100) and (111) of the host fluorite. Because of the wedge-like form of the inclusion, a shadow is seen on the right-hand side of the inclusion in transmitted light. Bobbejaankop granite, Sample 06377-22. G. A tubular fluid inclusion in a vuggy fluorite crystal. A very thin cavity (marked by an arrow) is connected to the inclusion from another, irregular, coalescenced inclusion, indicating that recrystallization took place after inclusion formation. A developing of a bulge is clearly seen inside the inclusion. Two separate gas bubbles may occur with an aqueous brine upon heating. Bobbejaankop granite, sample $06377-21$. H. A set of secondary fluid inclusions in the healed fracture of a fluorite crystal. The inclusions are contemporaneous and have trapped completely different gas/liquid ratios, owing to the apparently strong necking down. A younger microfracture (see arrow) cuts through the inclusion set. Bobbejaankop granite, Sample 06377-12. 

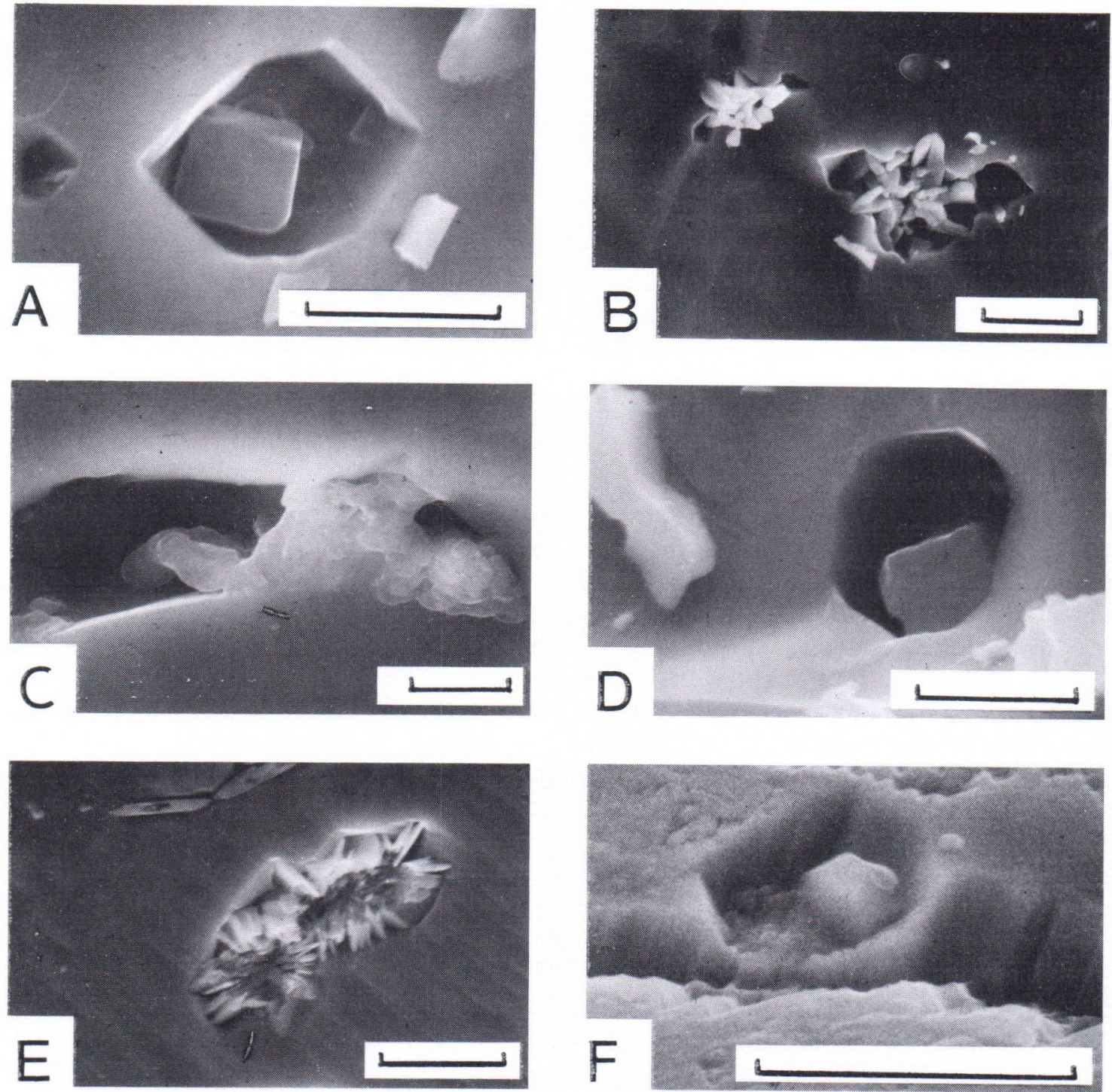

Fig. 3. The mode of occurrence of a few Zaaiplaats fluid inclusions in scanning electron microscope photomicrographs. The length of the scale bars in all photographs is $5 \mu \mathrm{m}$. A. A cube of halite in an opened fluid inclusion with a perfect negative crystal form of quartz, the host mineral. The halite crystal contains some potassium in solid solution of the system $\mathrm{NaCl}-\mathrm{KCl}$. Lease granite. Magnification $\times 6000$. Sample 06377-147. B. Trapped crystals of cassiterite in two opened fluid inclusions of host crystal, pyrite. Mineralized Bobbejaankop granite. $\times 3000$ magnification. Sample 06377-231. C. Scanning electron microscope photograph of dried-up fluid formed by evaporation of the liquid-phase released from the opened fluid inclusion. Several spot analyses of the fluid revealed the presence of the following elements: calcium, aluminium, chlorine, potassium, sodium, manganese, iron, titanium and zinc. The host mineral of this inclusion is quartz in the Lease granite. Magnification $\times 3000$. Sample 06377-147. D. An unidentified daughter mineral in a fluid inclusion of magmatic quartz of the Lease granite. The main elements of the mineral are sodium, chlorine, calcium and manganese. $\times 6000$ magnification. Sample 06366-147. E. An opened fluid inclusion in a fluorite crystal. The majority of the daughter crystals? are unidentified REE phases containing cerium, lanthanum and neodymium. Some of the daughter crystals consist merely of iron and titanium, and these phases are most probably titatium-bearing magnetites. $\times 4000$ magnification. Mineralized Bobbejaankop granite. Sample 06377-301. F. An opened inclusion in cassiterite contains a daughter crystal tentatively identified as xenotime, $\mathrm{Y}\left(\mathrm{PO}_{4}\right)$. Because the $\mathrm{Y}$ and $\mathrm{P}$ peaks overlap, the mineral could be a hydroxide, oxide, carbonate or borate of yttrium as well as phosphate. $\times 10000$ magnification. Bobbejaankop granite. Sample $06377-241$. 
cated the presence of cerium, lanthanum and neodymium (Fig. 3 E) but remained unidentified. Some small crystals of magnetite were found with these REE phases in the same fluid inclusions.

The main elements in the other daughter crystals of opened fluid inclusions analysed, were found to be iron, manganese, chlorine and calcium in addition to sodium and potassium. Only traces of sulphur were present.

The SEM-EDAX data indicate that chlorides such as $\mathrm{FeCl}_{3}$ and $\mathrm{CaCl}_{2}$ are common daughter crystals in the Zaaiplaats fluid inclusions even though they are observed far less often in the heating runs than are halite and sylvite.

The actual fluid composition was assessed for a few fluid inclusions in one of the Lease granite specimens. In these inclusions, which are only very rarely observed, the fluid formed solid precipitates by evaporation of the liquid released from the opened inclusions (Fig. 3 C). Several spot analyses of the precipitates revealed the following elements: calcium, aluminium, chlorine, potassium, sodium, manganese, iron, titanium and zinc. Although these analyses cannot be regarded as bulk analyses of the liquid phase of the inclusion fluids, the absence of fluorine and sulphur is conspicuous.

\section{Microthermometry results}

The Type III inclusions had the highest homogenization temperatures measured, generally above $480^{\circ} \mathrm{C}$. A number of these inclusions showed clear indications of leakage at temperatures above $400^{\circ} \mathrm{C}$. In addition, some of the samples decrepitated during the heating runs. Too few Type III inclusions were measured, however, to give any concentration of homogenization temperature values in their frequency.

The filling temperature range measured for the Lease granite fluid inclusions falls somewhat below that of the Bobbejaankop granite.
The inclusions measured were the Type III, $\mathrm{NaCl}$-saturated inclusions. The highest filling temperatures measured for the inclusions, which are obviously primary, were below $554^{\circ} \mathrm{C}$. The average homogenization temperatures for the Type I secondary inclusions in the Lease granite were about $180^{\circ} \mathrm{C}$.

The salinities for supersaturated Type III inclusions of the Bobbejaankop granite vary between 43 and 52 weight per cent $\mathrm{NaCl}$ determined graphically from the $\mathrm{NaCl}$ solubility curves of Sourirajan and Kennedy (1962) on the system $\mathrm{NaCl}-\mathrm{H}_{2} \mathrm{O}$ at elevated temperatures and pressures using the solution temperatures of the daughter $\mathrm{NaCl}$ crystals recorded in the heating runs. Likewise, the salinities in the supersaturated Type III inclusions of the Lease granite are between 44 and 51 weight per cent $\mathrm{NaCl}$, as derived from the solution temperatures of daughter $\mathrm{NaCl}$ crystals.

The secondary, highly saline Type I fluid inclusions in the Bobbejaankop and Lease granites gave very similar gross homogenization temperatures, usually in the range between $170^{\circ} \mathrm{C}$ and $220^{\circ} \mathrm{C}$. This demonstrates that the fluids were able to penetrate the granites because of microfracturing during the late hydrothermal stage, post-dating the epigenetic tin mineralization. The abundant and ubiquitous presence of the secondary inclusions with their highly saline fluid contents indicates that excess sodium and potassium were concentrated into the fluid phase, during the subsolidus recrystallization of the perthites in the Bobbejaankop and Lease granites, and were eventually sealed off in the secondary inclusions.

The primary inclusions in fluorite homogenized at the unusually high temperature range of $262^{\circ} \mathrm{C}$ to $318^{\circ} \mathrm{C}$. The degree of fill in the highest temperature inclusions can sometimes by very close to the critical density, and the homogenization behaviour is different from normal: the meniscus between the liquid and gas phases was observed to disappear upon heating. The fluorite specimens usually decrepitated at $330^{\circ} \mathrm{C}$. 


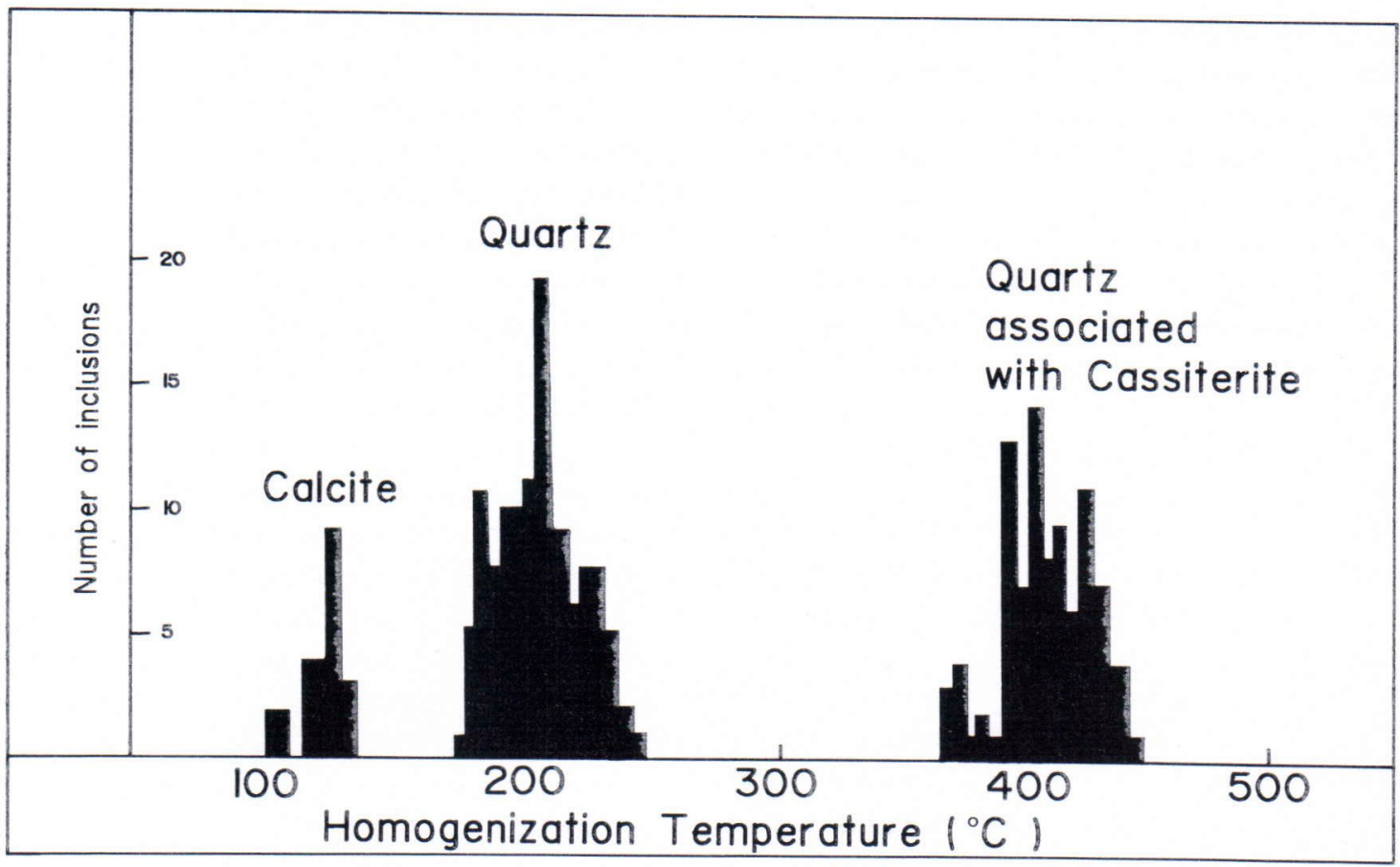

Fig. 4. Frequency distribution of the homogenization temperatures of the fluid inclusions of different origin in the vuggy quartz and calcite in the Bobbejaankop granite, and of the vuggy quartz associated with cassiterite in the miarolytic cavities of the greisenized Lease granite.

All the primary inclusions are Type II and have no daughter crystals.

Two separate gas bubbles occurred within the aqueous brine in some of the primary inclusions upon heating (Fig. $2 \mathrm{G}$ ), apparently because of leaking and a sudden decrease in pressure. In a number of freezing stage measurements the maximum salinities never exceeded 8.5 equivalent weight percent $\mathrm{NaCl}$.

The secondary inclusions in the fluorite samples have small unidentified daughter crystals. They tend to occur as long sets in the healed former fracture planes of the host fluorite, and have trapped highly variable liquid/vapour ratios, apparently because of intense necking down (Fig. $2 \mathrm{H}$ ). Very clear evidence exists that an extensive recrystallization followed inclusion formation in all fluorite samples (Fig. 2 G $-\mathrm{H})$. The interpretation of the microthermometric data is uncertain owing to the diffi- culty of determining appropriate pressure correction for inclusions that formed by necking down and coalescence. The primary fluid inclusions in the inner zone of vuggy quartz were found to belong to Types I and II (Fig. 2 D). Their filling temperatures are $248^{\circ} \mathrm{C}$ at the highest and $211^{\circ} \mathrm{C}$ at the lowest. The primary inclusions in the milky quartz zones homogenize in the temperature range $198^{\circ}-224^{\circ} \mathrm{C}$, slightly overlapping the filling temperatures of the inclusions in the inner zone. The outer zone gave the lowest homogenization temperatures for the primary inclusions: $178^{\circ}-206^{\circ} \mathrm{C}$. The fluids trapped in the outer zone inclusions were usually undersaturated.

The frequency distribution of the homogenization temperatures of the Type I and II inclusions (Fig. 4) indicates slightly different crystallization temperatures for the different zones in the vuggy quartz crystals, provided that the in- 
clusions are of primary origin. The fluctuations may only be a consequence of changing pressures, however.

All the inclusions of calcite specimens tested were Type II, two-phase inclusions. The filling temperatures are between $102^{\circ}$ and $134^{\circ} \mathrm{C}$ (Fig. 4 ), and the salinities, determined on the freezing stage, between 1.9 and 5.0 equivalent weight per cent $\mathrm{NaCl}$.

The homogenization temperatures for the $\mathrm{CO}_{2}-\mathrm{H}_{2} \mathrm{O}$ type (Type IV) inclusions in the vuggy quartz associated with cassiterite are depicted by the histogram of their frequency distribution in Figure 4 . The considerable variation in volume $\mathrm{CO}_{2} / \mathrm{H}_{2} \mathrm{O}$ ratios in these inclusions suggests that they were trapped from heterogeneous $\mathrm{CO}_{2}-\mathrm{H}_{2} \mathrm{O}$ fluid. All the observed inclusions in this homogenization temperature range (between $371^{\circ}$ and $438^{\circ} \mathrm{C}$ ) belong to the carbon dioxide-rich type; the origin of the inclusions is tentatively considered to be primary. The salinities are between 7.4 and 12.3 weight per cent $\mathrm{NaCl}$ obtained from the melting point of ice, but these values may be too high according to the criteria of Collings (1979) for carbonic inclusions.

\section{$\mathrm{SnO}_{2}$ crystal growth}

The laboratory experiments of Hesp and Rigby (1971) indicated that vapour-phase or pneumatolytic transport of tin by volatile halides is more likely to occur in the presence of chlorine than of fluorine. They conciuded that under the conditions of pneumatolysis, up to $800^{\circ} \mathrm{C}$, tin can be transported in the form of halides, even in the absence of water, and the order of transport efficiency is $\mathrm{SnI}_{4}>\mathrm{SnCl}_{4}>\mathrm{SnF}_{4}$. The first two halogens can effectively transport tin between $400^{\circ}$ and $600^{\circ} \mathrm{C}$, but fluorine is only effective at higher temperatures $\left(600^{\circ}-800^{\circ} \mathrm{C}\right)$.

The leaching of tin mainly from biotite by alkaline solutions containing $\mathrm{Na}^{2}, \mathrm{~K}^{+}, \mathrm{Cl}^{-}$, $\mathrm{SiO}_{3}^{2-}$ and $\mathrm{F}^{-}$ions, forming oxyfluoro stannates such as $\mathrm{Na}_{2}\left(\mathrm{Sn}(\mathrm{OH})_{x} \mathrm{~F}_{6-x}\right)$ soluble in aqueous fluid phase, may deposit cassiterite under favourable conditions (Barsukov and Volosov 1968).

Because the mechanism of tin concentration and transport in the geological processes appears to be an unsolved problem, few experiments were carried out by the author to study the phenomenon. According to the literature, $\mathrm{SnO}_{2}$ single crystals have been grown by a flux method and under hydrothermal conditions (Kurilchikova and Barsukov 1970) or from the vapour phase (Marley and MacAvoy 1961; Reed, Robby, and Mariano 1962; Takizawa and Sakurai 1973; Thiel and Helbig 1976).

The $\mathrm{SnO}_{2}$ crystals were grown by vapour reaction a technique frequently used in single crystal growth experiments. In this technique the vapours of starting materials are introduced with suitable carrier gases, thereby making it easy to control the rate of supply of the reactants.

Anhydrous stannic chloride $\left(\mathrm{SnCl}_{4}\right)$ and water vapour are suitable compounds for use as the starting materials of a vapour reaction method for $\mathrm{SnO}_{2}$ crystal growth, since the vapour pressures of these compounds at $20^{\circ} \mathrm{C}$ are 18.6 and $17.5 \mathrm{~mm} \mathrm{Hg}$, respectively. An ordinary horizontal electric furnace was used with a silica-glass tube inside the furnace. $\mathrm{SnCl}_{4}$ and $\mathrm{H}_{2} \mathrm{O}$ were stocked separately in glass vessels dipped in thermostats to maintain the vapour at constant pressures. Nitrogen was used as a carrier gas to transport $\mathrm{H}_{2} \mathrm{O}$ and $\mathrm{SnCl}_{4}$ into the growth zone.

In earlier crystal growth experiments synthetic cassiterite was only produced under high temperature conditions, i.e., between $1200^{\circ}$ and $1400^{\circ} \mathrm{C}$. The first objective of the present investigation was to determine the temperature range at which stannic oxide crystallizes; the second was to examine the effect of the carbon dioxide on the growth rate of synthetic cassiterite.

After calibrating the temperatures inside the furnace, small seed crystals of pure cassiterite 


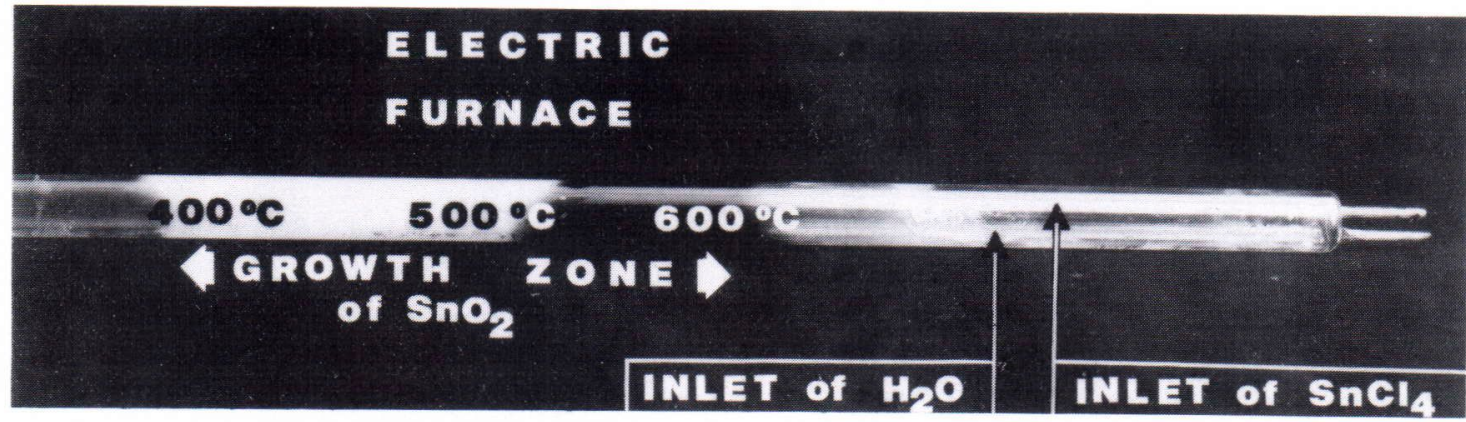

Fig. 5. Experimental arrangement for cassiterite crystal growth investigation with vapour reaction method.

were installed in the growth zone of the silicaglass testing tube (Fig. 5). For each run of 90 minutes, the flow rates of the reactants were kept as constant as possible. Before and after the experiments the seed crystals were weighed and indentified by the X-ray method using a Debye-Scherrer camera. The crystal forms were studied by scanning electron microscope (Fig. 6). Using vapour pressures of $18.6 \mathrm{~mm} \mathrm{Hg}$ for $\mathrm{SnCl}_{4}$ and of $17.5 \mathrm{~mm} \mathrm{Hg}$ for water vapour, and assuming that vapour and liquid are in

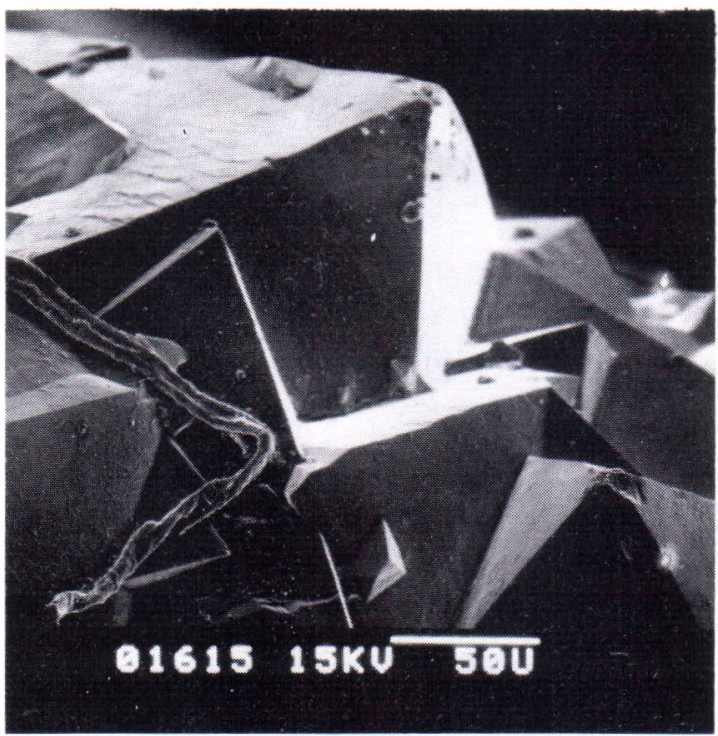

Fig. 6. The perfect tetragonal crystal form of the synthetic cassiterite is shown in this scanning electron microscope microphotograph. The scale bar is $50 \mu \mathrm{m}$. equilibrium in the $\mathrm{SnCl}_{4}$ vessel, and that $\mathrm{SnCl}_{4}$ behaves like an ideal gas, the reacting gases should deposit about $6.7 \mathrm{~g}$ of cassiterite at a flow rate of $400 \mathrm{~cm}^{3} /$ minute for the carrier gas.

The reaction is very vigorous and the accumulation of synthetic $\mathrm{SnO}_{2}$ on the seed $\mathrm{SnO}_{2}$ crystals is fastest in the narrow zone at $600^{\circ}$ where the reactants meet. However, a weight increase of 1.5 per cent was still measured for a seed crystal at $400^{\circ} \mathrm{C}$ after a run of 90 minutes. With the addition of carbon dioxide into the water vapour at a flow rate of $200 \mathrm{~cm}^{3} /$ minute, the increase in the weight of the seed is only 0.3 per cent at $400^{\circ} \mathrm{C}$.

\section{Discussion - granitic magmatism of the Bushveld complex and related tin mineralization}

The nature and particularly the emplacement history of a granitoid melt exerts a strong control upon its rare element and metal concentration. Because granitoids derive from a wide variety of source rocks the origin can also have an important influence upon subsequent ore potential (Taylor 1979). The processes that contribute towards concentrating tin within the igneous environment are diverse, and a large number of geological and physicochemical factors may play a role in the formation of the cassiterite deposits. Hesp and Rigby (1971) stated that the processes in connection with tin mineralization 
can be divided into two major groups, viz: (i) the tin from the primary source (magma) is concentrated through processes that are operative during the solidification of rocks, and it either crystallizes as cassiterite or concentrates in host minerals such as biotite; (ii) during postmagmatic metasomatism tin is released from the host minerals by hydrothermal solutions, and under favourable conditions these solutions hydrolyze to give cassiterite.

Differences of opinion exist concerning the manner of emplacement of the acid phase of the Bushveld Complex and the processes that gave rise to the stanniferous Bobbejaankop granite in the Zaaiplaats area.

According to Lenthall and Hunter (1977) and McCarthy and Hasty (1976), the Bobbejaankop granite formed from the Main granite mass of magma by in situ fractional crystallization after at least 85 per cent of the original magma mass had separated as cumulus minerals and intercumulus melt.

De Waal (1972) proposed that the stratiform character of the Main granite is a consequence of thermal metamorphism of various degrees and that the origin of the Bobbejaankop granite is not related to the Main granite.

The high thermal states of alkali feldspars in the lower Main granite (Ollila, 1981 and 1984 a) indicate the presence of only small quantities or the total absence of a volatile phase at the time of initial crystal growth that might have prevented the later development of higher ordering. Thus, at least this part of the Main granite might have undergone fractional crystallisation, which in turn led to concentration of tin in the melt by the process of differentiation-fractionation, i.e., tin was in excess of crystallochemical uptake (Taylor 1979; see also Fig. 7).

The mean tin content of the Main granite is $6.5 \mathrm{ppm}$ (Lenthal and Hunter 1977), which is about twice the average in acid plutonic rocks. Because the Main granite magma is most probably of crustal origin (Davies et al. 1970), it must have enriched in tin via original melting or partial melting and assimilation. After the magma had intruded into upper structural levels, crystallization would commence at the bottom of the sheet-like magma chamber and lead to further concentration of tin within the melt phase,

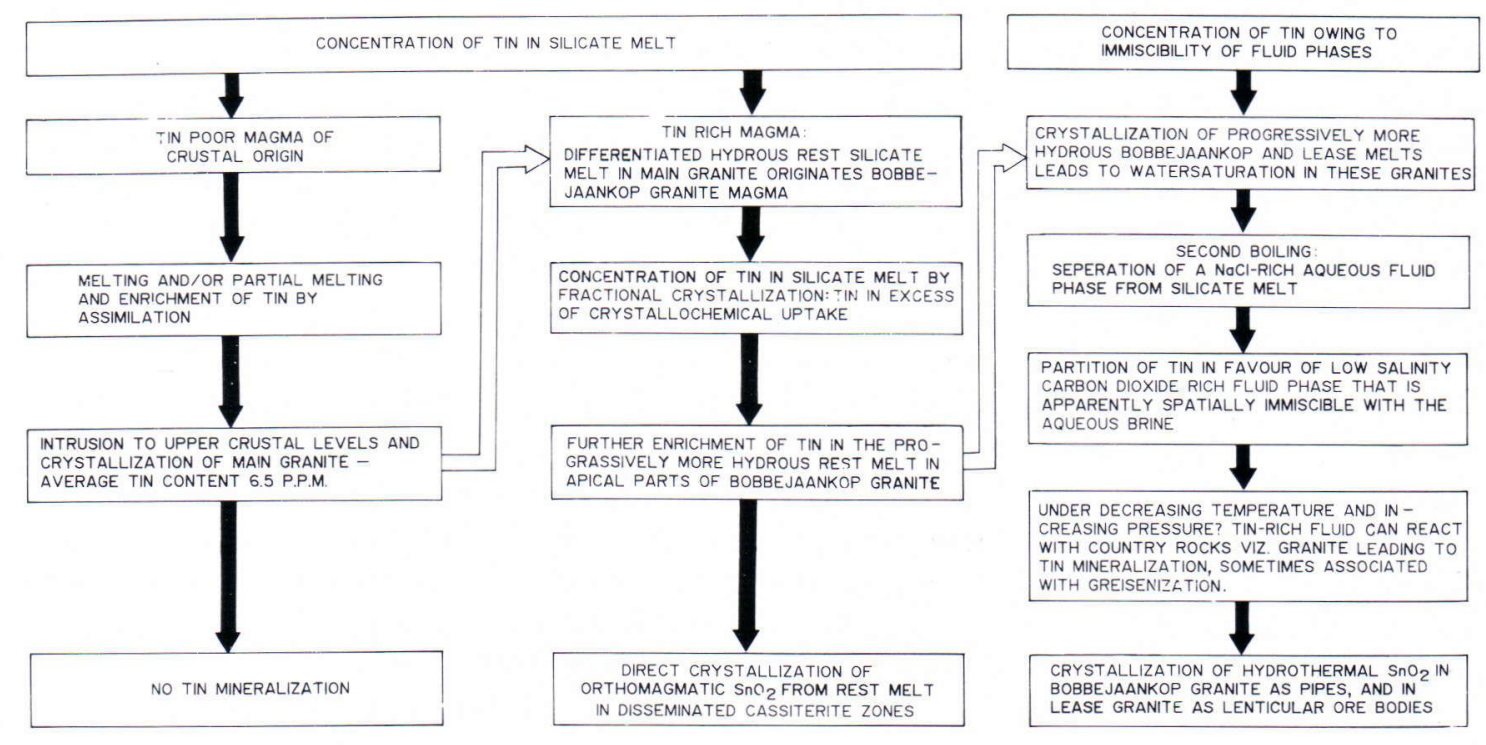

Fig. 7. Magmatic evolution of the Bushveld granites in the Zaaiplaats area and the proposed concentration path of tin within the silicate melt and the aqueous fluid phase. 
thereby giving rise to the hydrous Bobbejaankop granite magma (Fig. 7).

In the magmatic evolution of the Bobbejaankop granite, tin could have been concentrated into the apical parts of the granite cupolas in the following ways: (i) initial concentration of tin in the silicate melt and, after the »second boiling point» has been reached, eventual partition into the aqueous hydrothermal fluid, (ii) transport of tin in aqueous fluid by temperature and salinity gradients in the cooling pluton, (iii) pneumatolytic transport of tin as volatile halides, or (iv) concentration of tin from the country rocks by a circulatory system of descending fluids the intrusive granite functioning as a heat source.

Smith and Miller (1982) have recently traced the path of tin in the peraluminous Halifax pluton, Nova Scotia, in the context of magmatic evolution, and showed that it concentrated initially in the silicate melt and eventually partitioned into the aqueous hydrothermal fluid.

Continuation of the crystallization process, with or without a reaction between solid phases and silicate melt, leads to saturation of the residual-liquid with water and hence to the phenomenon generally termed second boiling, resurgent boiling or retrograde boiling. If the system is subjected to external pressure, it begins to »boil» once the value of the vapour pressure equals the external pressure, because there is a maximum in the vapour pressure curve with temperature. The "first boiling point» occurs with increasing temperature whereas the $» s e-$ cond boiling point» occurs with decreasing temperature. Thus, the »second boiling» results in separation of silicate melt and aqueous hydrothermal fluid in the cooling and crystallizing granite (Fig. 7).

The occurrence of Type III fluid inclusions with distinctly different degrees of filling in the same magmatic quartz crystals in generally accepted as evidence that the fluids were boiling when trapped. The interpretation of the microthermometric measurements on inclusions with trapped heterogeneous fluid is, however, complex.
A variable daughter salts/aqueous liquid ratio may indicate that the fluid was oversaturated at the time of trapping. According to data of Sourirajan and Kennedy (1962) the high temperature fluids in the Bobbejaankop granite inclusions were not supercritical at the time of entrapment. The critical temperatures of $\mathrm{NaCl}$ brines with about 19 to 46 weight per cent salt would fall in the range $600^{\circ}$ to $1000^{\circ} \mathrm{C}$, far above critical temperatures of pure water and above the measured homogenization temperatures.

The Type III fluid inclusions with 70 to 80 volume per cent vapour containing a $\mathrm{NaCl}$ daughter crystal in the condensed liquid, indicating a salinity of 30 weight per cent or more, cannot readily be explained without assuming that the inclusion walls were already wet with the highly saline fluid when the vapour was trapped. Because homogenization temperatures are related to trapping temperatures of inclusions only if they are homogeneous at the time of trapping, the homogenization temperatures measured cannot be interpreted with certainty as real trapping temperatures for the Type III inclusions with high gas/liquid volume ratios.

Furthermore, necking down if it has occurred, may have resulted in concentration of halite daughter crystals or vapour bubbles. The possibility of leakage before or during the heating runs must also be considered. If the fluid leaked out, particularly before the $\mathrm{NaCl}$ dissolved, the apparent concentration of salt would increase and the gross density would decrease, both yielding higher homogenization temperatures than the original trapping temperature of the fluid.

Both necking down and leakage or the trapping of a boiling fluid can yield homogenization temperatures that are very variable and sometimes even much higher than the maximum temperatures at the trapping of the fluid (Darimont and Coipel 1982).

The zones of disseminated cassiterite in the Bobbejaankop granite were probably formed by a magmatic process that apparently operated 
mainly in the crystal - silicate melt system. The mode of crystallization of the Bobbejaankop granite must have been determinant in the localization of the disseminated zones. The aqueous fluid obviously did not act as a localizing factor in the magmatic tin deposition. Thus, the bulk of the tin could have partioned into the silicate melt, or rather, crystallized before the initial water-saturation of the Bobbejaankop granite.

Assuming, however, that the vapour and aqueous brine phases trapped in Type III inclusions originated through the "second boiling» and that the disseminated zones were crystallized by the transitional process, viz. in the coexisting crystals - volatile phase system, the data indicate that, at high temperatures ( $>$ $500^{\circ} \mathrm{C}$ ), halite may precipitate out of solution under a pressure-temperature drop that leads to loss of salinity and that this affects the equilibrium of the reaction $\mathrm{HCl} \rightleftharpoons \mathrm{H}^{+}+\mathrm{Cl}^{-}$. As proved experimentally, decreasing temperature promotes dissociation of $\mathrm{HCl}$. The dissociation of $\mathrm{HCl}$, in turn, could explain why orthomagmatic $\mathrm{SnO}_{2}$ precipitated in the disseminated zones.

The pneumatolytic theory of tin deposition maintains that tin in the gaseous fluid phase can give rise to volatile halides such as $\mathrm{SnCl}_{4}$, which move to the apical parts of the granite cupolas at submagmatic temperatures. Crystal growth experiments using the equation $\mathrm{SnCl}_{4}$ $+2 \mathrm{H}_{2} \mathrm{O} \rightleftharpoons \mathrm{SnO}_{2}+4 \mathrm{HCl}$ showed that this vapour phase reaction is possible down to $400^{\circ} \mathrm{C}$ and that addition of $\mathrm{CO}_{2}$ gas to the $\mathrm{H}_{2} \mathrm{O}$ vapour reduces the growth rate of $\mathrm{SnO}_{2}$. The experimental arrangements in this study, however, were, not appropriate for measuring the solubility of $\mathrm{SnCl}_{4}$ in water vapour and the effect of increased $\mathrm{CO}_{2}$ partial pressure of it; therefore the results cannot be applied to natural conditions.

Hydrothermal tin deposition in the greisenized sheets of the Lease granite may start with the volatile halides, e.g. $\mathrm{SnCl}_{4}$, reacting with the wall-rock granite. This may be followed by hydrolysis reactions, viz. chloritization of biotite and sericitization of orthoclase, both of which involve incorporation of $\mathrm{H}^{+}$.

The host granite of the lenticular ore-bodies and pipes can be greisenized either at constant or decreasing temperature by shifting from the potassium feldspar stability field to the mica field.

From the experimental concentration ratios for feldspar and mica hydrolysis equilibria it is evident that feldspar alteration leads to decreasing $\mathrm{KCl} / \mathrm{HCl}$ and $\mathrm{NaCl} / \mathrm{HCl}$ total concentration ratios (See Hemley 1975). Thus the host rock alteration can, in fact, accommodate the four molecules of $\mathrm{HCl}$ from the tin-IV-chloride + water vapour reaction. The greisenization is probably due to the development of a two-fluid phase field at submagmatic temperatures, at which undissociated $\mathrm{HCl}$ would partition in favour of the more gaseous fluid and very low $\mathrm{KCl} / \mathrm{HCl}$ and $\mathrm{NaCl} / \mathrm{HCl}$ ratios would result, this in turn, explains the loss of stability of the feldspars. The last stage of economic mineralization, the pipe-ores, cross-cut the disseminated orebodies. The pipe-ores sometimes show a breakdown of mica, involving both $\mathrm{H}^{+}$and $\mathrm{SO}_{4}^{2-}$ fixation in the process of alunitization.

The highly variable vapour-liquid ratios in Type IV inclusions indicate the trapping of a heterogeneous $\mathrm{CO}_{2}-\mathrm{H}_{2} \mathrm{O}$ fluid; the homogenization temperatures are obviously very near the true trapping temperatures without pressure correction.

Further evidence that the moderately saline (7.4-12.3 weight per cent $\mathrm{NaCl}$ ) tin-bearing fluid was immiscibe with the hydrosaline fluid is the abundant occurrence of the $\mathrm{NaCl}-\mathrm{KCl}-$ $\mathrm{H}_{2} \mathrm{O}$ fluid (salinities up to 60 per cent $\mathrm{NaCl}$ ) in the secondary fluid inclusions of the Bobbejaankop and Lease granites. This indicates that the dilute $\mathrm{CO}_{2}-\mathrm{H}_{2} \mathrm{O}$-rich and the $\mathrm{NaCl}-\mathrm{KCl}$ $-\mathrm{H}_{2} \mathrm{O}$ fluid systems may have been coexisting at the time of their separation and that the $\mathrm{f}_{\mathrm{CO}_{2}}$ may have controlled the transport and deposition of tin in the late magmatic process. 
The mechanism by which cassiterite ultimately precipitates from the hydrothermal fluid phase in epigenetic tin deposition is virtually unknown. The most likely mechanisms for cassiterite and associated mineral deposition are: (i) simple cooling of the ore-forming hydrothermal fluids, (ii) dilution of the ore-forming fluid with cool meteoric water, (iii) mixing of two fluids of different chemical composition, and (iv) interaction of the ore-forming fluid with wall rocks.

The fluid inclusion observations do not, however, provide evidence of the presence and mixing of a hydrothermal ore-forming fluid of magmatic origin with meteoric water during tin mineralization. Tin in the low density, gaseous $\mathrm{CO}_{2}$-rich fluid phase may have lost its solubility as a consequence of cooling of the fluid and also as a consequence of the interaction of this fluid with the wall-rock granites. Thus, the changing physico-chemical conditions, i.e. the possible increase in total pressure or, rather, $\mathrm{CO}_{2}$ partial pressure of the ore-forming hydrothermal fluid, may have controlled the solubility, transport and deposition of tin at sub-magmatic temperatures.

Under decreasing temperatures the fluid pressures were eventually built up so high because of the increasing volume of the fluid phase by "second boiling" that the system underwent drastic opening: an explosive breccia has been found in connection with one pipe orebody

\section{References}

Barsukov, V. L., \& A. G. Volosov, 1968. New approach to geochemical prospecting for mineralization located deep below the surface. Geol. of ore deposits 10, 6, 3-9.

Collins, P. L. F., 1979. Gas hydrates in $\mathrm{CO}_{2}$-bearing fluid inclusions and the use of freezing data for estimation of salinity. Econ. Geol. 74, 1435-1444.

Darimont, A. \& J. Coipel, 1982. Dispersion des températures d'homogénéisation des inclusions aqueuses - ébullition ou division par éranglement. Chem. Geol. 37, 151-163.
(Strauss 1954). Consideration of rock mechanics (Professor C. Roering, personal communication) and the geological setting of the tin deposits indicates that the hydrothermal fluids can, indeed, have caused the hydraulic fracturing of the country-rocks, viz. granophyre, above the mineralized Bobbejaankop granite.

When the $\mathrm{CO}_{2}-\mathrm{H}_{2} \mathrm{O}$-bearing fluid phase separated, the boron and fluorine compounds partitioned in favour of this fluid with metal compounds such as tin, copper, tungsten and a small amount of molybdenum. The distribution of tourmaline, which occurs chiefly with quartz in the outer shells of the ore pipes, could be explained by the assumption that boron entered the gaseous phase with various amounts of other incompatible elements.

The occurrence of cerium, lanthanum, neodymium and yttrium as possible daughter minerals in fluid inclusions in fluorite and cassiterite of the mineralized Bobbejaankop granite shows, however, the complexity of the composition of the ore-forming fluids at Zaaiplaats.

Acknowledgements. This paper is published with the permission of the president of MINTEK (Council for Mineral Technology, Randburg, South Africa). The experimental work was carried out at the Witwatersrand, Stellenbosch and Rand Afrikaans Universities and at MINTEK. The author wishes to thank Dr. Kari Kinnunen and Prof. J.P.R. de Villiers for critical reading of the manuscript, and MINTEK for financial support.

Davies, R. D., H. L. Allsopp, A. J. Erlank \& W. I. Mouton, 1970. Sr isotope studies on various layered intrusions in Southern Africa. Geol. Soc. S. Afr. Spec. Publ. 1, Editors: D. Visser and G. von Gruenewaldt, 579593.

De Waal. S. A., 1972. The Bushveld granites in the Zaaiplaats area. Geol. Soc. S. Afr. Trans. 76, 135-148.

Hemley, J. J., 1975. Activity relations and stabilities in alkali feldspar and mica alteration relations. Econ. Geol. 70, 577-594.

Hesp, W. R.\& D. Rigby, 1971. The transport of tin in acid igneous rocks. Pac. Geol. 4, 135-152. 
Kurilćhikova, G. E. \& V. L. Barsukov, 1970. Stability of hydroxystannate complexes and experimental crystallization of cassiterite under hydrothermal conditions. Geochem. Int. 7, 31-37.

Lenthall, D. H. \& D. R. Hunter, 1977. The geochemistry of the Bushveld granites in the Potgietersrus tin-field. Precambrian Res. 5, 359-400.

Marley, J. A. \& T. C. MacAvoy, 1961. Growth of stannic oxide crystals from vapour phase. J. Appl. Phys. 32, 2504-2505.

McCarthy, T. S. \& R. A. Hasty, 1976. Trace element distribution patterns and their relationship to the crystallization of granitic melts. Geochim. Cosmochim. Acta 40, $1351-1358$.

Ollila, J. T., 1981. A fluid inclusion and mineralogical study of tin deposits and rocks associated with the Bushveld Complex at the Zaaiplaats, Rooiberg and Union tin mines in the Central Transvaal, South Africa. Ph.D. thesis, Rand Afrikaans Univ., Johannesb., 257 p.

-, 1984 a. The crystallization of a tin-bearing granitoid suite: the Bushveld granites in the Zaaiplaats area, South Africa. Bull. Geol. Soc. Finland 56, 75-88.

Reed, T. B., J. T. Robby \& A. Mariano, 1962. Vapour growth of tin oxide crystals. J. Appl. Phys. 33, 10141015 .
Söhnge, P. G., 1944. The structure, ore genesis and mineral sequence of the cassiterite deposits in the Zaaiplaats tin mine, Potgietersrus District, Transvaal. Geol. Soc. S. Afr. Trans. 47, 157-182.

Sourirajan, S. \& G. C. Kennedy, 1962. The system $\mathrm{H}_{2} \mathrm{O}-$ $\mathrm{NaCl}$ at elevated temperatures and pressures. Am. J. Sci. 260, 115-141.

Smith, T. E. \& P. M. Miller, 1982. Solidification and crystallization of a stanniferous granitoid pluton, Nova Scotia, Canada. In: Metallization Associated with Acid Magmatism. John Wiley et. Sons Ltd., Editor: A.N. Evans. 385 p.

Strauss, C. A., 1954. The geology and mineral deposits of the Potgietersrus tin-fields. Mem. Geol. Surv. S. Afr. $46,241 \mathrm{p}$.

Takizawa, T.\& T. Sakurai, 1973. Vapour growth of $\mathrm{SnO}_{2}$ crystals. Jap. J. Appl. Phys. 12, 1323-1325.

Taylor, R. G., 1979. Geology of tin deposits. Elsevier, Amsterdam, 543 p.

Thiel, B. \& R. Helbig, 1976. Growth of $\mathrm{SnO}_{2}$ single crystals by a vapour phase reaction method. J. Cryst. Growth 32, 259-264.

Manuscript received, July 12, 1983. 